intensity were characteristic of aurora, which is not very common at this season of the year, I think.

Birstal Hill, Leicester, August $\mathbf{I}_{3}$

F. T. МотT

We had a fine aurora here last night (IIth). There was a bright bank of uniform glow till iI p.m., when it suddenly broke into streamers, some of which reached $40^{\circ}$ or $45^{\circ}$ in height, the glow extending along $100^{\circ}$ or $120^{\circ}$ of the horizon. There was no colour, and by midnight it had all faded out.

Whitby, August I2

B. W. S.

\section{Height of the Aurora}

I sHaLl be glad if you will allow me the use of your columns to point out that there is really less uncertainty about this element than is usually supposed, and that there are two methods of measuring auroral heights which give accordant results. The first is that based upon the measurements of the altitude and amplitude of auroral arches, and which gives the results mentioned by Mr. Rand Capron. That these results should have so wide a range is probably owing to the fact that they proceed upon an assumption which may or may not be correct, yiz., that the arch is part of a circle having the magnetic pole for its centre. Still the mean result from this method would seem to be reliable, especially if care were taken to exclude doubtful measurements from the list. Possibly we may assume that this method gives a height not far from roo miles for the ordinary arch. I speak particularly of the white auroral arch with or without uncoloured streamers that forms, I suppose, 95 per cent. of the auroral phenomena visible in this country. These arches are formed for the most part over a portion of the earth considerably to the (magnetic) north of these islands, but occasionally they would seem to be formed over our heads. Mr. Capron in his work on "Aurora and their Spectra" mentions one such instance, though he appends no explanation of the phenomenon, but in the course of ten years' observations I have myself secn three such arches. Indeed they are perfectly well known to observers in Scotland and the north of England, though I have never suen them in the south. As early as the year 1843 the height of these zenithal arches had been trigonometrically com puted from observations made in different localities in Britain, with the result of proving them to be at an uniform height of 70 to 74 miles above the earth. ${ }^{1}$ There is much less liability to error in these results than in the determination of the height of a meteor, and a single pair of satisfactory observations will yield a value within one or two miles of the actual elevation.

That auroral arches are ever formed much below this limit beg leave to doubt. I am aware of the accounts which would place them between the eye and natural objects, but such assertions are far from having the weight of accurate measurements, and I have yet to find a case of a supposed low aurora, the evid snce of which is above criticism.

I do not wish to assert that the streamers at right angles to thesc arches may not be frequently visible at a less height, just as they undoubtedly reach to a much greater elevation in the region where the auroral crown is formed. But to fix either the superior or inferior limit is precisely one of those questions which we can have no hope of solving by direct measurement, since the length of the streamer varies with the force of electric discharge. This is shown by the fact that in an active aurora some streamers extend only a short distance from the arch, while others will climb up to the vanishing point, or crown.

To carry these remarks so as to include the question of coloured aurorac would oblige me to trespass more upon your space than I am willing to do on this occasion.

Orwell Park Observatory, Ipswich John I. Prummer

\section{Fire-Ball}

ON the evening of the $\mathbf{r}$ th a very brilliant fire-ball fell at 8h. 30m. G.M.T. It was first observed at an elevation of about $25^{\circ}$ above the E.S.E. horizon, and its path was inclined at an angle of about $35^{\circ}$ to the horizon. It was lost in the mist near the south horizon. 'There was no explosion or noise of any kind. The daylight was still fairly strong, and yet the light of the meteor was very dazzling.

Stonyhurst Observatory, August 15

${ }^{I}$ I give these figures from memory, as I have no library at hand to which to rcfer, but I have no doubt that they are strictly correct. Mr. Capron may perhans find some information on the point in the published works of the late Prof. Phillips, who was onc of the observers engaged in these investigations about the date I have named, or they may be verified upon the first appcarance of a zenithal arch.

\section{Atmospheric Phenomenon}

A currous phenomenon was observed here after sunset the night before last, and again in a less degree last night.

Looking across from this point to the position of the sun at and after setting, the line of sight crosses about three miles of sea, then about the same distance or rather less of projecting high ground, and beyond that many miles of sea again. On Tuesday (Ioth) the sun set in a hot haze, and half an hour after there appeared on the edge of the projecting land what looked like tongues of flame fifteen to thirty minutes in height, lasting from two to four seconds each, and then disappearing in different places, sometimes half a dozen at a time. At the same time there was more or less of a flickering light along the whole line of projecting land.

My first impression was that it was an optical illusion, and the second that a moor was on fire behind the ridge, and that these were points of flame. The first was negatived by the fact that four others beside myself (two of them with very keen sight) saw the lights independently in the same places; and the second by the gradual fading of the light as the evening became darker, the "tongues" retaining pretty much their relative brightness to the general glow until both faded out.

The day had been extremely hot, and the evening was sultry, with motionless air. I imagine the appearance was due to irregular refraction, arising from heated currents of air from the cooling land, and that the circumstance of the slice of land with its currents occurring between the two stretches of homogeneous air over the sea allowed the effect to be seen without being masked, as it would have been had there been intervening land. But I never saw it before, and don't remember to have seen it described.

Whitby, August 12

B. W. S.

\section{Intellect in Brutes}

INSTINCT apart, cases of intelligence in animals are very numerous, of the affections still more numerous. Comte was of opinion that the affections were even more highly developed in animals than in men. The dog will lay down life for the man he loves, the horse will do so likewise. We have all heard of Greyfriars Bobby, if that be the creature's name. But instances crowd on the memory. A few years back, during a heavy gale, a sweep of the spanker-boom drove the master of a Leith and London smack into the sea. Instantly the ship's dog bounded in after, and, sustaining the drowning man, both passed grandly into the eternities together. I have known cats who let themselves into the dwelling house at pleasure, and at least three dogs who were wont to deposit the pennies given them on the counter of some baker or pastry-cook in return for values received. I used to meet on the highway a dog who rode behind his master's groom. The bardest trot never seemed to discompose his seat. Even birds-not merely trained birds-sometimes display singular attainments. I knew a lady who had a singing duck, but being one day at a loss for a couple, she sacrificed the songstress to make up a pair. One wishes that she had displayed a little more humanity ; as also a clergyman, not a hundred miles from where I sit, who ordered a goose that had evinced the warmest attachment to be slain by reason of the poor bird having followed him on the occasion of paying a visit into a friend's drawing room.

When a boy I used to spend many a holiday at a farmer's house in the County Armagh. I there experienced great kindness, enjoying myself as much as was well possible in the open air, the garden, and the stubble fields. Besides human beings, $=\mathrm{I}$ had numerous playmates too in the kine, swine, dogs, fowl, horned cattle, and horses about the place, and indeed was never tired in observing their modes of living and acting. The great house-dog used of ten to play with a large hog. They alternately chased and faced one another till the hog's chaps would froth again actually with the excitement of the sport. At first I supposed that the pig did not like it, but in this I was mistaken. One day a strange dog, an immense brute, made his appearance, and attacked the house-dog, who was evidently getting the worst of it, when who should come to the rescue but the hog, who instantly jumped on the strange dog's back, assailing him at the same time with hoof and tooth. Placed thus between two fires, the stranger beat a speedy retreat, leaving the friends complete masters of the situation.

I think I was about ten years old when my parents went to reside at a place called Fairlawn, situated on a gentle eminence a few miles from the mutually contiguous towns of Moy and 